\title{
KOMPETENSI KOMUNIKASI WANITA DALAM ORGANISASI KEAGAMAAN MUSLIMAT DAN 'AISYIYAH DI SURABAYA
}

\author{
Ali Nurdin \\ UIN Sunan Ampel Surabaya \\ Email: ali.nurdin@uinsby.ac.id
}

Diterima : 25 Desember 2019

Disetujui : 11 Februari 2020

Diterbitkan : 24 Februari 2020

\begin{abstract}
Abstrak
Tujuan penelitian ini untuk mendeskripsikan kompetensi komunikasi pemimpin organisasi Muslimat dan 'Aisyiyah di Surabaya. Penelitian menggunakan jenis deskriptif kualitatif. Teknik pengumpulan data dilakukan dengan wawancara, pengamatan, dan telaah dokumen. Data dianalisis dengan model alir melalui proses reduksi data, penyajian, kesimpulan dan verifikasi. Hasil penelitian ini mendeskripsikan bahwa kompetensi komunikasi yang dimiliki pemimpin Muslimat dan 'Aisyiyah dalam pembinaan anggota diimplementasikan dalam pembagian tugas dan kewenangan yang terstruktur dalam organisasi. Kompetensi komunikasi pemimpin diimplementasikan dalam proses pengkaderan formal dan informal yang dilakukan secara terkendali dan berdasar kesepakatan kolektif yang dilakukan antara pengurus dan anggota. Model komunikasi kepemimpinan organisasi Muslimat dan 'Aisyiyah ditandai dengan adanya saling menghargai keputusan yang logis dan kreatif dari kesepakatan anggota organisasi. Faktor pendukung keberhasilan komunikasi organisasi Muslimat dan 'Aisyiyah adalah adanya kolektivitas antar anggota, dan faktor yang menghambat adalah kejenuhan dan kesibukan para anggota.
\end{abstract}

Kata Kunci : 'Aisyiyah, Kompetensi Komunikasi, Muslimat, Organisasi

\begin{abstract}
The purpose of this study is to describe the communication competencies of Muslimat and Aisyiyah organization leaders in Surabaya. Research uses descriptive qualitative type. Data collection techniques are done by interview, observation, and document review. Data were analyzed with flow models through the process of data reduction, presentation, conclusion and verification. The results of this study describe that the communication competencies of the leaders of Muslimat and Aisyiyah in coaching members are implemented in the division of tasks and authority that is structured in the organization. Leader communication competence is implemented in formal and informal cadre processes carried out in a controlled manner and based on collective agreements made between leaders and members. The communication model of the leadership of Muslimat and Aisyiyah organizations is characterized by mutual respect for logical and creative decisions from the agreement of organizational members. The supporting factors for the successful communication of Muslimat and Aisyiyah organizations are the collectivity between members, and the inhibiting factors are the boredom and busyness of the members.
\end{abstract}

Keywords: 'Aisyiyah, Communication Competence, Muslimat, Organization 


\section{PENDAHULUAN}

Hasil penelitian terdahulu menjelaskan bahwa organisasi keagamaan wanita memiliki peran dalam pencerahan dan pemberdayaan perempuan sebagai modal sosial bagi Indonesia (Ahdiah, 2011 : 523-534), aspek psikologis kepemimpinan wanita (Meizara, Dewi, \& Basti, 2016 : 175-181), pola kepemimpinan perempuan (Nurasmah, 2018), dibolehkannya wanita memimpin organisasi dengan lebih mengutamakan peran domestik (keluarga) daripada ruang publik (Asmani, 2015 : 48), karakteristik kepemimpinan perempuan yang cenderung emosional, pasif, mudah terpengaruh, adanya ketergantungan, tidak agresif, dan tidak kompetetif (Situmorang, 2011 : 132). Peran perempuan dalam kepemimpinan yang masih dibawah kendali laki-laki dan menempatkannya sebagai pelengkap kepemimpinan laki-laki (Rahim, 2016 : 293). Potret 'Aisyiyah sebagai gerakan politik (Dzuhayatin, 2009 : 345-359), kunci utama dalam sukses kehidupan organisasi adalah adanya komunikasi dan opini positif yang dikembangkan (Fatikh \& Panuju, 2018 : 22). Keharmonisan komunikasi dalam organisasi dapat diibaratkan seperti membangun keharmonisan dalam keluarga, anak ibarat anggota dalam sebuah organisasi yang memerlukan kasih sayang, pemimpin organisasi ibarat kepala keluarga yang mampu membagi peran masing-masing anggota keluarga, dan perlunya komunikasi yang efektif dan positif dalam membentuk sebuah keharmonisan agar tercapai tujuan organisasi (Nidyansari, $2018: 274$ ).

Aspek komunikasi yang melekat dalam organisasi wanita tercermin dalam konstruk yang dibangun dalam mengelola organisasi dengan menanamkan kepercayaan dan identitas diri untuk meningkatkan kompetensi komunikasi (Indriastuti, 2018 : 17), peningkatan sumber daya manusia untuk mendukung kompetensi komunikasi (Rahminawati et al., 2006 : 143), meningkatkan kompetensi komunikasi politik untuk menduduki jabatan strategis dari elemen wanita (Zamroni, 2013 : 143), komunikasi dengan karakteristik budaya perempuan (Nurhidayah, 2017 : 209), dan komunikasi kepemimpinan Muslimat lebih toleran dalam mengelola kepemimpinan politik dan sosial dibandingkan dengan 'Aisyiyah yang cenderung membatasi diri dalam dunia politik dan fokus pada pengembangan organisasi (Imamah \& Firlana, 2019 : 229).

Hasil penelitian di atas dapat memetakan aktivitas wanita dalam organisasi dalam perspektif agama, sosial, politik, budaya, kepemimpinan, dan komunikasi. Nilai kebaruan (novelty) dalam penelitian ini adalah mensinergikan aspek-aspek yang melekat dalam aktivitas organisasi tersebut dalam bentuk kompetensi komunikasi wanita dalam mengelola organisasi keagamaan.

Penelitian ini dilakukan atas dasar fenomena bahwa; pertama, Muslimat dan 'Aisyiyah adalah organisasi keagamaan terbesar yang ada di Indonesia dan telah terbukti memberikan peran penting dalam mengawal perubahan sosial-keagamaan dalam kehidupan masyarakat. Kedua, aktivitas kaum wanita dalam organisasi Muslimat dan 'Aisyiyah melahirkan kompetensi kepemimpinan dalam skala lokal dan nasional. Ketiga, organisasi Muslimat dan 'Aisyiyah memberikan peran dalam menjaga kerukunan internal dan eksternal antar agama ditengah tekanan politik praktis. Keempat, pimpinan kedua organisasi Muslimat dan 'Aisyiyah memiliki peran untuk mengendalikan anggota dalam kehidupan bermasyarakat dan bernegara. Kelima, mayoritas anggota organisasi Muslimat dan 'Aisyiyah memiliki loyalitas, ketundukan, dan ketaatan pada pimpinannya. 
Potensi individu yang dimiliki seorang wanita dapat dikembangkan dalam lingkup organisasi. Organisasi adalah sekumpulan orang dalam jumlah yang lebih besar dengan struktur yang lebih terarah dan dengan tujuan yang sama, saling berinteraksi untuk mewujudkan tujuan organisasi (Nurdin, 2014 : 5). Organisasi dibentuk berdasarkan kesepakatan bersama untuk mewujudkan serta memberikan dampak baik untuk keuntungan organisasi maupun masyarakat sekitar.

Di Indonesia terdapat dua organisasi keagamaan terbesar, yaitu Nahdatul Ulama didirikan tahun 1926 dan Muhammadiyah didirikan tahun 1912. Keduanya merupakan organisasi Islam yang didirikan untuk mengupayakan perbaikan dan pengembangan pendidikan yang bertujuan untuk membebaskan umat Islam dari keterbelakangan dan kebodohan. Kedua organisasi keagamaan ini memiliki organisasi wanita yaitu Muslimat di bawah naungan Nahdatul Ulama dan 'Aisyiyah di bawah naungan Muhammadiyah.

Muslimat dan 'Aisyiyah adalah organisasi keagamaan yang berusaha memberikan keseimbangan dalam kehidupan sosial, kultural, agama, dan politik. Kedua organisasi ini jauh dari tujuan politik, namun peran serta kedua organisasi ini tidak dapat lepas dari kekuasaan politik yang berkembang. Tugas berat organisasi ini menjadi tantangan bagi kaum wanita untuk dapat menampilkan peran dan kompetensinya dalam mengembangkan organisasi.

Teori yang digunakan untuk menjelaskan fenomena komunikasi wanita dalam mengelola organisasi yaitu teori hubungan manusiawi yang menjelaskan bahwa aspek manusia adalah elemen terpenting dalam mengembangkan organisasi. Sumber daya manusia harus diperhatikan dalam mengelola organisasi dengan memberikan perhatian dan apreseasi atau apa yang dilakukan untuk memajukan organisasi. Teori komunikasi kewenangan menjelaskan bahwa maju dan berkembangnya sebuah organisasi tergantung pada kemampuan seseorang dalam berkomunikasi dan kerjasama (Nurdin, 2014 : 93-94). Dua teori ini memberikan sudut pandang secara teoritis tentang kompetensi komunikasi wanita dalam mengelola organisasi.

Syarat sebuah pesan komunikasi dapat diterima oleh anggota organisasi dan stakeholder lain adalah adanya kompetensi komunikasi. Kompetensi merupakan kemampuan yang dimiliki individu yang meliputi pengetahuan (knowlage), keahlian (skill), dan tingkah laku (attitude)(Nurdin, 2015 : 30). Ketiga kompetensi ini harus dimiliki oleh orang yang mengelola organisasi.

Kompetensi komunikasi kaum wanita perlu pembuktian dalam mengawal dan menjalankan tugas organisasi. Kompetensi komunikasi adalah bagian dari kompetensi sosial. Kompetensi sosial adalah kemampuan individu berupa perilaku dan keterampilan yang digunakan untuk mengawasi lingkungan sosialnya, atau kemampuan individu untuk mengatasi setiap rintangan dalam kehidupan kesehariannya. Syarat untuk mencapai kompetensi adalah pemahaman bahasa, memiliki keterampilan sosial, pengetahuan sosial, sensitivitas sosial, kemampuan memahami budaya yang meliputi adat, norma, dan organisasi sosial (Korhonen, 2002 : 27-28). Secara sederhana kompetensi komunikasi dapat didefinisikan sebagai kemampuan seseorang yang memadahi untuk diyakini dan diikuti pesan dan ajakannya (Nurdin, $2015: 26$ ). 
Tujuan penelitian ini adalah untuk memahami dan mendeskripsikan kompetensi komunikasi yang dimiliki pemimpin organisasi keagamaan Muslimat dan 'Aisyiyah di Surabaya yang meliputi kompetensi komunikasi dalam pembinaan anggota, kompetensi komunikasi dalam proses pengkaderan anggota, kompetensi komunikasi kepemimpinan organisasi wanita, dan faktor pendukung dan penghambat komunikasi dalam organisasi wanita Muslimat dan 'Aisyiyah.

\section{METODOLOGI PENELITIAN}

Penelitian dilakukan dengan metode kualitatif untuk mendeskripsikan kompetensi komunikasi wanita dalam mengelola organisasi keagamaan secara mendalam dan holistik. Peneliti mengeksplorasi data lisan dan tulisan dari informan sesuai fokus penelitian (Moeleong, 2008 : 5). Sasaran penelitian ini adalah organisasi keagamaan wanita Muslimat dan 'Aisyiyah di Kota Surabaya. Fokus penelitiannya adalah kompetensi komunikasi wanita dalam mengelola organisasi keagamaan dalam level regional, dan berlokasi di Kota Surabaya.

Teknik pengumpulan data dalam penelitian ini dilakukan dengan wawancara mendalam, observasi, dan telaah dokumen. Peneliti melakukan wawancara mendalam kepada pimpinan atau ketua organisasi keagamaan Muslimat dan 'Aisyiyah dengan kriteria minimal aktif dalam organisasi selama dua tahun dan menjadi pimpinan organisasi. Informan dipilih secara informal dengan cara interaktif (percakapan), melalui pertanyaan terbuka, dan diperkuat dengan observasi tentang kegiatan yang dilakukan dalam mengelola organisasi. Telaah dokumen dilakukan dengan jenis tinjauan integratif (Kuswarno, 2009 : 62-63) terhadap pengetahuan yang sudah pasti melalui literatur, buku referensi, dokumen-dokumen, dan jurnal-jurnal yang relevan dengan topik penelitian.

Analisis data penelitian dimulai dengan menelaah semua data yang ditemukan, kemudian dilakukan reduksi data. Melakukan klasifikasi data yang dapat menggambarkan kompetensi komunikasi wanita dalam mengelola organisasi sebagaimana tuntutan teori. Analisis data dilakukan menggunakan analisis data model alir yang terdiri dari tiga alur kegiatan yang terjadi secara bersamaan yaitu reduksi data, penyajian data, penarikan kesimpulan dan verifikasi (Miles \& Huberman, 1992 : 18). Tiga alur dalam analisis data ini merupakan bagian yang integral sehingga saling berhubungan antara tahapan yang satu dengan yang lain. Analisis dilakukan secara kontinyu dari awal sampai akhir penelitian.

\section{HASIL DAN PEMBAHASAN}

\section{Profil Organisasi Muslimat dan 'Aisyiyah di Surabaya}

Organisasi Muslimat lahir secara resmi pada tanggal 29 Maret 1946 M, bertepatan dengan tanggal 26 Rabiul Akhir $1465 \mathrm{H}$. Secara substansi, sejarah partisipasi warga Nahdlatul Ulama (NU) dari kaum perempuan selalu menyertai sejak NU dideklarasikan pada tahun 1926. Keterlibatan kaum perempuan NU dalam organisasi pada awalnya terjadi perbedaan pendapat diantara para ulama NU. Seiring dengan semakin banyaknya kaum perempuan yang aktif dan berpartisipasi dalam segala aktivitas NU, maka keterlibatan kaum perempuan NU disetujui dan dapat dinaungi dalam sebuah wadah organisasi otonom 
(Imamah \& Firlana, 2019 : 230). Pertama kali yang menjadi ketua Muslimat adalah Ny. Chadijah Pasuruan. Berdirinya Muslimat NU secara otomatis dapat menampung aspirasi dari kaum perempuan NU yang berkeinginan aktif berorganisasi dan memperjuangkan berbagai persoalan yang dihadapi kaum perempuan. Muslimat merupakan wadah inspirasi dan manifestasi untuk menggerakkan kaum wanita demi perubahan, yang bergerak dibidang kesejahteraan sosial, pendidikan, ekonomi, dan politik (Diana, 2015 : 56). Struktur kepengurusan berada pada tingkat nasional (pusat), wilayah (provinsi), daerah (kota / kabupaten), kecamatan, dan tingkat desa (Muslimat NU, 2015). Muslimat NU memiliki kepengurusan di tingkat kecamatan yang dinamakan dengan Pimpinan Anak Cabang Muslimat yang tersebar pada 31 kecamatan di Surabaya.

'Aisyiyah adalah organisasi wanita di bawah naungan organisasi besar Islam Muhammadiyah yang didirikan pada 19 Mei 1917 M bertepatan dengan 27 Rajab $1335 \mathrm{H}$. Organisasi ini adalah gerakan dakwah Islam berdasarkan amar ma'ruf nahi munkar dan tajdid berdasarkan Al-Qur'an dan As-Sunnah yang bergerak dalam bidang pendidikan, kesehatan, kesejahteraan sosial, ekonomi, dan pemberdayaan masyarakat (Wati \& Agustono, 2017 : 102). Nama Aisyiyah terinspirasi dari nama istri Nabi Muhammad yaitu Aisyah yang dikenal cerdas dan mumpuni. Jika Muhammadiyah berarti pengikut Nabi Muhammad, maka Aisyiyah adalah pengikut Aisyah. Keduanya merupakan pasangan yang serasi dalam berdakwah, Aisyiyah akan berjuang berdampingan bersama Muhammadiyah. Siti Badriah merupakan Ketua pertama Aisyiyah yang dikader oleh Kyai Dahlan. Muhammadiyah bersama 'Aisyiyah melakukan gerakan dakwah yang tidak membedakan jenis kelamin sebagai kararakter gerakan dakwahnya. Semangat pembaruan yang berpijak pada paham Islam berkemajuan tetap menjadi suluh bagi Aisyiyah (Pimpinan Pusat Aisyiyah, 2007 : 7). Struktur kepengurusan berada pada tingkat nasional (pusat), wilayah (propinsi), daerah (kota/ kabupaten), kecamatan, dan tingkat desa (Aisyiyah, 2019). 'Aisyiyah memiliki kepengurusan di tingkat kecamatan yang dinamakan dengan Pimpinan Cabang 'Aisyiyah yang tersebar pada 31 kecamatan di Surabaya.

\section{Kompetensi Komunikasi dalam Pembinaan Anggota}

Komunikasi memiliki peran penting dalam pembinaan anggota organisasi. Aspek komunikasi memberikan kontribusi dalam meningkatkan kualitas hubungan antara pimpinan dengan anggotanya. Komunikasi harmonis yang dibangun dalam organisasi mampu meminimalisir konflik yang terjadi dalam organisasi. Peran komunikasi dalam pembinaan anggota organisasi dapat diidentifikasi sebagai berikut; pertama, komunikasi mampu menyampaikan informasi dan pengetahuan yang menimbulkan tindakan kerja sama antar pimpinan dengan anggota. Kedua, komunikasi mampu menggerakkan anggota untuk melakukan suatu tindakan. Ketiga, komunikasi memiliki peran dalam mengajak, meyakinkan, dan mempengaruhi perilaku anggota organisasi (Nurdin, 2014 : 22-25).

Organisasi dibentuk melalui komunikasi dan saling berinteraksi satu sama lain untuk mencapai tujuan organisasi, termasuk proses komunikasi dalam pembinaan anggota (Effendy, 2006 : 114). Komunikasi dapat meningkatkan kualitas organisasi dan dapat merealisasikan tujuan organisasi melalui pembinaan anggota organisasi. Oleh karena itu diperlukan kompetensi komunikasi dalam mengarahkan anggotanya agar proses pembinaan 
anggota berjalan dengan lancar. Organisasi wanita Muslimat dan 'Aisyiyah merupakan organisasi keagamaan yang melakukan pembinaan anggota agar sesuai dengan ideologi organisasinya.

Seorang pemimpin harus dapat menerapkan komunikasi yang efektif dalam organisasi dengan memiliki kemampuan relasi dengan orang lain, membimbing, mengarahkan, memotivasi, dan menginspirasi anggotanya. Keahlian komunikasi yang dimiliki seorang pemimpin mampu menumbuhkan, menciptakan pemahaman, dan kepercayaan yang diperlukan untuk mendorong orang lain untuk mengikuti pemimpin. Dalam perspektif komunikasi, bukanlah seorang pemimpin jika tidak memiliki komunikasi yang efektif (Barrett, $2014: 5$ ).

Konteks komunikasi dalam pembinaan anggota adalah adanya elemen dalam pembinaan yang tidak dapat terlepas dari komunikasi melalui elemen tujuan, proses, materi, dan cara yang dilakukan dalam pembinaan (Sari, 2018 : 52). Pembinaan dalam model pengajian juga dapat dikategorikan dalam komunikasi kelompok kecil dan besar tergantung dari jumlah peserta komunikasi yang hadir (Nurdin, 2014 : 6).

Komunikasi dalam proses pembinaan anggota Muslimat dilakukan melalui tingkatan struktur organisasi. Struktur Pimpinan Anak Cabang (PAC) yang ada di tingkat kecamatan di Surabaya membawahi kepengurusan Ranting di tingkat kelurahan, dan kepengurusan Anak Ranting di tingkat Rukun Warga (RW). Anggota organisasi berada pada wilayah kepengurusan Anak Ranting yang selalu dikoordinasikan dengan kepengurusan pada level atasnya. Model struktur ini menjadikan pengurus Anak Ranting sebagai ujung tombak dalam berkomunikasi dengan anggota.

Pembinaan anggota dilakukan oleh pengurus Muslimat dengan model pengajian. Waktu yang diperlukan sekitar dua jam dengan materi kajian tafsir dan fiqih. Materi disampaikan oleh narasumber yang memiliki kredibilitas dan keahlian dalam bidangnya. Peran pemimpin dalam model pembinaan anggota ini adalah sebagai penyelenggara kegiatan pengajian yang dihadiri oleh seluruh pengurus dan anggota. Pengajian di tingkat Pengurus Cabang dilakukan dalam waktu satu bulan sekali, sedangkan pengajian di tingkat pengurus Anak Cabang dan Anak Ranting dilakukan secara bervariasi, ada yang satu minggu sekali, ada pula yang dua minggu sekali. Pernyataan ini diperkuat pengakuan informan sebagai berikut:

Kegiatan pembinaan dalam model pengajian di tingkat Anak Ranting dihadiri seluruh anggota dan pengurus Anak Ranting. Peserta atau jama'ah pengajian yang hadir antara 70 sampai 100 orang dalam waktu satu minggu sekali di tingkat Pengurus Anak Cabang, dan satu bulan sekali tingkat Cabang. Rangkaian isi kegiatan terdiri dari membaca istighosah, tahlil, dan baca sholawat, dilanjutkan pengajian (Wawancara dengan Lilik Fadhilah, 16 April 2019).

Proses komunikasi pembinaan anggota pada organisasi Muslimat dapat dilihat dari hasil pengamatan pada salah satu kegiatan pengajian rutin yang diadakan dua minggu sekali di PAC Muslimat Krembangan. Kegiatannya meliputi pembacaan Yasin, tahlil, sholawat, istighosah, serta ceramah agama. Kegiatan ini sudah mencerminkan kompetensi komunikasi 
organisasi melalui pembagian tugas (job description) sesuai dengan keahlian masing-masing anggota. Salah satu kompetensi komunikasi yang harus dimiliki dalam kegiatan ini adalah memiliki pengetahuan tentang agama Islam, mampu membaca Al-Qur'an dengan fasih, berperilaku yang baik, serta memahami tipe audiens. Kompetensi yang dimiliki ini dapat menambah kredibilitas pengurus dan anggota dapat mengikuti kegiatan tersebut.

Selain kegiatan pengajian, proses komunikasi pembinaan anggota pada organisasi Muslimat juga dilakukan dengan memberi pelatihan tentang kepemimpinan untuk menyiapkan kader yang mumpuni. Hal ini diperkuat dengan hasil wawancara dengan salah satu Pimpinan Cabang Muslimat kecamatan Sawahan sebagai berikut:

Model pelatihan kepemimpinan bagi anggota dilakukan untuk menyiapkan estafet kepemimpinan di masa mendatang. Penentuan peserta dilakukan seleksi berdasarkan tingkat keaktifan dan loyalitasnya pada organisasi. Penyelenggara pelatihan ini adalah pengurus Anak Cabang, Jadi setiap pimpinan mempersiapkan anggotanya untuk pelatihan tersebut. Pelatihan dilakukan secara insidental, tidak terjadwal seperti model pengajian (Wawancara dengan Hj. Mining, 13 Mei 2019).

Kompetensi komunikasi juga ditunjukkan oleh organisasi wanita 'Aisyiyah dalam proses pembinaan anggota yang dilakukan secara terstruktur melalui Badan Pembantu Pimpinan di antaranya Majelis Tabligh, Majelis Kesejahteraan Sosial, Majelis Dikdasmen, Majelis Kesehatan, Majelis Ekonomi, Majelis Kader, dan Lembaga Kebudayaan. Pada setiap majelis inilah, pembinaan anggota dilakukan sesuai dengan program yang ada. Pada setiap majelis ini para pengurus memiliki kompetensi dalam membina anggotanya.

Majelis Tabligh melakukan pembinaan anggota dengan model pengajian rutin. Majelis Kesejahteraan Sosial membina anggotanya dengan model kegiatan konsultasi keluarga. Majelis Kesejahteraan Sosial memberikan bantuan bagi anggota yang memiliki masalah ekonomi dengan membagi sembako dan mencarikan donatur. Majelis Dikdasmen melakukan pembinaan anggota melalui lembaga pendidikan untuk membentuk manusia yang utuh, berilmu, dan berkarakter. Majelis Kader melakukan pembinaan anggota untuk meningkatkan kualitas kader yang memiliki integritas, komitmen, militansi, ghirah, solidaritas, ukhuwah, daya juang, wawasan, dan professional berbasis ideologi 'Aisyiyah. Majelis Kesehatan melakukan pembinaan anggota dengan kegiatan posyandu untuk balita, remaja, dan lansia. Majelis Ekonomi melakukan pembinaan anggota dengan mengajak para anggota untuk berwirausaha dan mengikuti pelatihan di Daerah. Lembaga Kebudayaan melakukan pembinaan anggota dengan pengembangan khasanah budaya Islami.

Semua majelis ini dikumpulkan dalam pertemuan periodik setiap satu bulan sekali yang diikuti oleh semua Ranting (Wawancara dengan Kasiati, 5 Mei 2019).

Selain kegiatan periodik di atas, Pimpinan Cabang 'Aisyiyah Kecamatan Bulak melakukan pembinaan anggota dengan program Qaryah Thoyyibah. Kompetensi komunikasi yang dimiliki pengurus 'Aisyiyah dibuktikan dengan adanya efek kegiatan tersebut yaitu terciptanya kesadaran masyarakat tentang fungsi tanaman disekitarnya. Hal ini diperkuat dengan hasil wawancara dengan penasihat Ranting Kecamatan Bulak sebagai berikut : 
Selain pembinaan dengan model pengajian dalam waktu satu bulan sekali, Ada juga kegiatan dalam bentuk pemberdayaan anggota melalui kegiatan menanam tanaman obat-obatan dan pohon-pohon. Pada awalnya memang agak sulit meyakinkan masyarakat untuk menanam tanaman, sedikit demi sedikit hasilnya sudah mulai terasa dengan banyaknya anggota yang mulai gemar menanam bunga-bunga, atau tanaman yang lain. Jadi tidak hanya menjemur ikan saja, tetapi juga mulai adanya kesadaran terhadap pentingnya memelihara lingkungan sekitar (Wawancara dengan Mulyana, 1 Mei 2019).

Kompetensi komunikasi dalam pembinaan anggota yang dimiliki pengurus Muslimat dan 'Aisyiyah dilihat dalam sudut pandang teori hubungan manusiawi termasuk dalam kategori pemimpin yang mampu memberikan peran penting dalam mengendalikan anggota baik secara formal maupun informal (Nurdin, 2014 : 93-94 ). Flauto (1999) membatasi kompetensi komunikasi dengan dua perspektif yaitu kognitif dan perilaku. Perspektif kognitif dalam kompetensi komunikasi pengurus Muslimat dan 'Aisyyah adalah kemampuan dalam menyampaikan pengetahuan kepada anggotanya. Sedangkan perspektif perilakunya adalah kemampuan individu dalam berperilaku komunikatif sesuai dengan situasi tertentu. (Jubaedah, 2009 : 405).

Menurut teori komunikasi kewenangan melihat bahwa komunikasi yang dijalankan organisasi Muslimat dan 'Aisyiyah dalam pembinaan angota lebih mengutamakan pendekatan kemanusiaan, yaitu melihat orang sebagai suatu sistem yang dinamis dan lebih mengedepankan sistem kerjasama antar anggota organisasi (Nurdin, 2014 : 93-94 ). Salah satu syarat komunikasi efektif dalam kepemimpinan Muslimat dan 'Aisyiyah adalah adanya kompetensi komunikasi. Seorang pemimpin yang memiliki kompetensi komunikasi seringkali dipersepsikan oleh anggotanya sebagai pemimpin yang efektif dalam menjalankan organisasinya (Jubaedah, $2009: 411$ ).

Berdasarkan data di atas, kompetensi komunikasi yang dimiliki pengurus organisasi Muslimat dan 'Aisyiyah dalam pembinaan anggotanya berhasil membentuk dan mengarahkan anggotanya untuk aktif dalam kegiatan yang bersifat positif yang dapat memberi dampak pada masyarakat sekitar. Pembinaan yang dilakukan oleh pimpinan yang kompeten akan menghasilkan anggota yang kompeten, apabila komunikasi dilakukan dengan benar.

\section{Kompetensi Komunikasi dalam Pengkaderan Anggota}

Pengkaderan adalah sebuah proses dan cara mendidik seseorang menjadi kader. Kader adalah seseorang yang diharapkan melanjutkan regenerasi kepemimpinan di masa yang akan datang. Kaderisasi kepemimpinan adalah proses mempersiapkan seseorang untuk menjadi pemimpin pengganti dimasa depan, yang akan memikul tanggung jawab penting di lingkungan organisasi (Rival \& Mulyadi, 2010 : 96). Kaderisasi merupakan hal yang penting bagi sebuah organisasi, dan merupakan inti dari kelanjutan perjuangan organisasi kedepannya. Kaderisasi bertujuan untuk menciptakan kader yang memiliki jiwa pemimpin, emosi yang terkontrol, kreatif dan mampu memberikan solusi untuk setiap permasalahan, serta menjadi teladan bagi anggotanya (Makruf, $2019: 47$ ). 
Konteks komunikasi dalam proses pengkaderan dapat dikaji dalam perspektif komunikasi organisasi dalam kategori komunikasi ke bawah (Down Ward Communication) yaitu penyampaian pesan pada kader secara instruktif tentang aturan organisasi, etika, nilai, dan motivasi dalam berorganisasi (Nurdin, $2014: 22$ ).

Pengkaderan dalam Muslimat dilakukan melalui proses selektif tentang calon kader yang memiliki kriteria berprestasi, loyal, dan memiliki dedikasi dan semangat yang tinggi pada organisasi. Kompetensi individual yang dimiki seorang kader dapat menentukan masa depannya dalam organisasi melalui proses selektif-instruktif (Rival \& Mulyadi, 2010 : 9698). Pernyataan ini diperkuat hasil wawancara dengan Wakil Anak Cabang Muslimat NU Kecamatan Gayungan Surabaya sebagai berikut:

Semua anggota Muslimat adalah kader, yaitu anggota yang aktif dalam kegiatan Muslimat. Dari semua anggota tersebut kemudian diseleksi siapa yang kira-kira layak dijadikan sebagai pemimpin di masa depan. Pengurus memilih kader mana yang pantas ditingkatan pengetahuannya untuk diikutkan dalam pelatihan-pelatihan tentang organisasi yang diadakan oleh Muslimat (Wawancara dengan Yasifun, 8 Mei 2019).

Proses kaderisasi anggota organisasi Muslimat lebih mengutamakan kaum muda. Mereka berfikir bahwa generasi muda yang seharusnya selalu ditampilkan (dikader). Organisasi ini menyadari bahwa anak-anak muda memiliki semangat dan antusias yang tinggi, sehingga mereka dapat belajar menjadi pemimpin, dan belajar bertanggung jawab pada tugas yang telah diberikan oleh para pengurus organisasi Muslimat. Melalui instruksi pengurus dalam penunjukan sebagai petugas tersebut mereka dapat berlatih kompetensi, dan kaderisasi ini dilakukan secara bergilir agar adil.

Ada persyaratan tertentu yang harus dipenuhi untuk menjadi pengurus Muslimat yaitu diantaranya mereka harus bergabung dan aktif dari tingkat terendah yaitu Ranting. Seringkali pengurus Muslimat mengambil jalan pragmatis dengan mengkader dan menunjuk mahasiswi yang memiliki kompetensi dan mau berkontribusi tinggi di dalam organisasi Muslimat, walaupun sebelumnya tidak pernah bergabung di Muslimat, dan ini melanggar ketentuan yang ada (Wawancara dengan Lilik Fadhilah, 16 April 2019).

Kaderisasi 'Aisyiyah diarahkan untuk membentuk kader yang mampu menggerakkan, memajukan, dan mengembangkan organisasi serta meningkatnya kuantitas dan kualitas kader yang memiliki integritas, kompetensi keagamaan dan keilmuan, militansi, ghirah perjuangan, sikap dan tindakan yang berpegang pada nilai-nilai Islam berkemajuan. 'Aisyiyah mengadakan kaderisasi dalam memilih pemimpin organisasi yang diselenggarakan empat tahun sekali dengan menggunakan sistem voting untuk memilih pemimpin (Wawancara dengan Kastiani, 9 Mei 2019).

Ada dua cara dalam proses kaderisasi anggota 'Aisyiyah yaitu cara formal dan informal. Cara formal dikenal dengan sebutan Baitul Arqam yaitu sistem pengkaderan dalam 'Aisyiyah yang berorientasi pada pembinaan ideologi (Islam dan Ke-Muhammadiyahan) dan kepemimpinan untuk menciptakan kesamaan dan kesatuan sikap, integritas, wawasan, cara 
berfikir dan bertindak di kalangan pimpinan maupun anggota untuk mewujudkan visi dan misi 'Aisyiyah. Sedangkan cara informal, dikenal dengan istilah kader kintilan, yaitu pada saat anggota 'Aisyiyah mengajak anaknya untuk datang rapat. Pada tingkat Daerah atau Pimpinan Daerah, 'Aisyiyah memiliki sekolah kader (Wawancara dengan Elen, 1 Mei 2019).

Ada stereotype yang berkembang di masyarakat yang menganggap bahwa mengikuti sebuah organisasi adalah sebuah hal yang merepotkan. Menyikapi fenomena ini 'Aisyiyah melakukan kaderisasi dengan berbagai cara yaitu model komunikasi kekeluargaan, mengajak anggota dari keluarga terdekat. Model penjaringan kader melalui kegiatan outbond dan seminar, dan juga melalui jaringan lembaga-lembaga pendidikan Muhammdiyah (Wawancara dengan Lilik, 9 Mei 2019).

'Aisyiyah memiliki Majelis Kader yang melaksanakan proses pengkaderan secara rutin satu minggu sekali. Dalam majelis ini, dapat dilihat proses kaderisasi anggota yang memiliki banyak potensi. Tidak hanya ibu-ibu saja yang terlibat, tetapi lebih banyak anak remaja perempuan.

Komunikasi pengkaderan yang dilakukan oleh pengurus organisasi Muslimat dan 'Aisyiyah ini memiliki kontrol yang ketat pada anggotanya. Menurut teori komunikasi kewenangan, kerberhasilan komunikasi yang dilakukan pemimpin pada anggotanya ditandai dengan penerimaan pesan oleh anggota organisasi. Jika anggota menolak pesan komunikasi yang disampaikan maka kewenangan komunikasi pemimpin tertolak. Kompetensi komunikasi harus dimiliki seorang pengurus agar pesan komunikasi dapat diterima anggota. Dalam pandangan teori hubungan manusiawi, seorang kader adalah masa depan organisasi. Kader harus mendapat perhatian utama agar masa depan organisasi yang berbasis "orang" ini memiliki keberlanjutan masa depan yang cerah (Nurdin, 2014 : 93-94).

Pengakaderan anggota Muslimat dan 'Aisyiyah dapat dikaji dalam perspektif pola komunikasi organisasi. Kecenderungan pola komunikasi dalam pengkaderan menggunakan pola komunikasi roda dan bintang. Pola komunikasi roda menjelaskan tentang keseluruhan informasi berada pada struktur puncak organisasi (top management). Pola komunikasi bintang mengacu pada keterbukaan komunikasi dan informasi yang dilakukan oleh seluruh elemen anggota organisasi tanpa melihat jabatan dalam organisasi (Makruf, 2019 : 57, Nurdin, $2014: 108)$.

\section{Kompetensi Komunikasi Kepemimpinan Organisasi Wanita}

Kepemimpinan adalah dinamika aktivitas dalam organisasi yang diwarnai oleh proses saling mempengaruhi dalam menentukan tujuan untuk mencapai visi dan misi organisasi. Persepsi anggota organisasi dibentuk atas hasil interpretasi yang saling mempengaruhi dalam melaksanakan tugas organisasi yaitu pengorganisasian dalam mencapai sasaran yang telah disepakati, memelihara hubungan kerjasama, menyatukan kerja individu dan kelompok, dan memperoleh dukungan dari lingkungan internal, bahkan eksternal kelompok atau organisasi (Rival \& Mulyadi, 2010 : 2). Sebuah kepemimpinan memiliki fungsi-fungsi diantaranya adalah instruksi yang bersifat satu arah dan dua arah, bersifat partisipatif yang berusaha mengaktifkan anggota dalam pengambilan keputusan, adanya pendelegasian kepada anggota, dan adanya pengendalian aktivitas anggota dalam mencapai tujuan bersama (Rival \& Mulyadi, $2010: 34-35)$. 
Setiap organisasi baik bersifat formal atau non formal memiliki model atau gaya kepemimpinan masing-masing yang bergantung pada karakteristik pemimpin dan para anggota organisasi tersebut. Dalam memimpin organisasi terdapat kemudahan dan hambatan yang harus dilalui oleh setiap pemimpin. Ada tiga pola dasar dalam kepemimpian seseorang, yaitu; pertama, pola kepemimpinan berbasis pelaksanaan tugas. Kedua, pola kepemimpinan berbasis pelaksanaan hubungan kerjasama, dan Ketiga, pola kepemimpinan berbasis kepentingan atas hasil yang dicapai (Rival \& Mulyadi, 2010 : 36).

Model kepemimpinan dalam setiap organisasi dapat mempengaruhi kinerja para anggota dalam mencapai tujuan. Oleh karena itu, bagi seorang pemimpin diperlukan kompetensi tidak hanya pengetahuannya yang luas tentang organisasi dan tujuan yang ingin dicapai, tetapi juga harus memiliki keterampilan dalam berkomunikasi dengan para anggota yang disertai dengan perilaku baik yang dapat dijadikan teladan bagi anggotanya. Keterampilan komunikasi ini meliputi kemampuan memahami apa yang diperlukan oleh anggota sehingga pemimpin mampu merespon dengan baik dan benar. Seorang pemimpin juga harus memberikan ruang kesempatan yang luas bagi anggotanya untuk menyampaikan pendapat agar ada pesan timbal balik antara atasan dengan bawahan. Seorang pemimpin juga harus memiliki kemampuan mendengarkan tentang apa yang anggotanya sampaikan, tidak hanya berbicara saja.

Dinamika yang terjadi dalam kepemimpinan organisasi adalah adalah timbulnya klik, yaitu terbentuk kelompok kecil yang dapat menghambat aktivitas organisasi. Peristiwa ini sering terjadi dalam suatu organisasi. Oleh karena itu, diperlukan pemimpin yang kompeten, yang mampu merangkul, mendengarkan, menerima aspirasi anggotanya, bijaksana dan bertanggung jawab sesuai dengan jabatannya sebagai pemimpin. Kepemimpinan dalam organisasi yang efektif adalah kunci utama dalam suksesnya sebuah organisasi (Effendy, 2006 : 117). Apabila seorang pemimpin dapat berkomunikasi dengan efektif maka ia mampu membuat bawahannya melakukan kegiatan tertentu dengan kesadaran, kegairahan, dan kegembiraan. Dengan suasana yang seperti itu akan dapat diharapkan hasil yang memuaskan.

Model komunikasi kepemimpinan organisasi Muslimat menggunakan model birokrasi yang lazim digunakan organisasi yang lain, yaitu adanya sebuah prosedur yang telah ditetapkan oleh organisasi, dan anggota menjalankan kegiatan-kegiatan yang telah dikonsep dan direncanakan oleh organisasi (Nurdin, 2014 : 91). Model komunikasi kepemimpinan yang lain adalah transformasional yaitu cenderung mengandalkan gaya kepemimpinan yang visioner dengan menawarkan visi yang jelas untuk menginspirasi anggota untuk mencapai tujuan organisasi (Barrett, 2014 : 346). Hal ini sesuai dengan pernyataan informan sebagai berikut :

Tata kelola adminsitrasi dilakukan dengan prosedur yang ditetapkan organisasi, jika ada kegiatan, anggota diundang melalui surat, hanya saja akhir-akhir ini mulai bergeser dengan menggunakan media sosial. Pengurus selalu menyampaikan tujuan organisasi agar dapat dipahami oleh anggota dengan banyak memberi tauladan yang positif (Wawancara dengan $\mathrm{Hj}$. Mining, 13 Mei 2019). 
Organisasi Muslimat menggunakan model komunikasi kepemimpinan demokratis seperti lazimnya organisasi keagamaan wanita yang lain. Pemimpin demokratis adalah pendengar dan kolaborator yang sangat baik, Mereka ahli dalam mengikutsertakan orang lain dalam membuat ide dan penyelesaian masalah (Barrett, 2014 : 344). Pernyataan ini diperkuat hasil wawancara dengan Ketua PAC Muslimat NU kecamatan Pakal sebagai berikut :

Jika ada masalah apapun saya selalu mengajak musyawarah pengurus, jika memang membutuhkan peran anggota, kami juga akan mengajak anggota untuk bermusyawarah (Wawancara dengan $\mathrm{Hj}$. Chusniyah Machfudz, 1 Mei 2019).

Berbeda dengan model komunikasi kepemimpinan pada organisasi Muslimat, 'Aisyiyah menggunakan model komunikasi kepemimpinan kolektif kolegial yaitu model kepemimpinan yang tidak hanya didasarkan pada pribadi satu orang atau satu tokoh saja (Harianto, 2018 : 130), model kepemimpinan bersama tim (Pramitha, 2018 : 127) yang bersifat musyawarah dan mufakat untuk setiap keputusan yang diambil dalam organisasi. Hal ini sesuai dengan pernyataan informan sebagai berikut:

Setiap anggota pengurus ikut bertanggung jawab pada setiap keputusan yang dibuat dalam organisasi. Dalam menjalankan kepemimpinannya, Ketua Pimpinan Cabang 'Aisyiyah (PCA) bersama para anggota mengadakan rapat periodik guna mengevaluasi kinerja masing-masing majelis. Selain itu rapat periodik juga ditujukan sebagai ajang problem solving apabila ditemukan suatu permasalahan dalam menjalankan program kerja yang telah dirancang (Wawancara dengan Nur Hasanah, 7 Mei 2019).

Komunikasi kepemimpinan 'Aisyiyah dalam organisasi lebih mengedepankan komunikasi persuasif dengan mengajak para anggotanya agar mempunyai rasa memiliki dan bertanggung jawab atas pekerjaannya. Hal ini sesuai dengan hasil wawancara dengan Pimpinan Cabang 'Aisyiyah Kecamatan Sawahan sebagai berikut:

Saya selalu mengajak semua pimpinan cabang dan seluruh majelis untuk mempunyai rasa memiliki terhadap 'Aisyiyah ini. Kita harus bertanggung jawab atas semua yang telah dibebankkan atau diamanahkan. Seperti setelah pertemuan periodik, semua majelis itu laporan semua kegiatan apa yang dilaksanakan. Jadi setiap majelis ingin mengadakan kegiatan harus rapat dulu, sehingga ketua maupun wakilnya mengetahui (Wawancara dengan Soelikah, 13 Mei 2019).

Komunikasi kepemimpinan organisasi wanita Muslimat dan 'Aisyiyah dalam sudut pandang teori komunikasi kewenangan menegaskan peran yang utama seorang pemimpin adalah memberikan ruang yang lebih kepada anggota untuk menyampaikan aspirasinya sebagai bentuk kewenangan yang dimiliki seorang pemimpin. Kewenangan yang diberikan pada anggota merupakan sebuah bentuk kepercayaan. Dengan kepercayaan tersebut, rasa 
memiliki organisasi lebih besar, dan tangungjawabnya juga semakin besar jika diberi kepercayaan (Nurdin, 2014 : 93).

Gaya tim (team style) adalah gaya kepemimpinan pada organisasi Muslimat dan 'Aisyiyah ditandai dengan adanya saling menghargai keputusan yang logis dan kreatif dari kesepakatan anggota organisasi. Tipe pemimpin seperti ini memiliki keinginan untuk mendengarkan, mencari gagasan, pendapat, dan sikap anggota organisasi. Sinergi pendapat antar anggota ini kemudian dirubahnya sebagai pendapat organisasi dengan argumentasi yang utuh dan solid (Barrett, $2014: 344$ ).

\section{Faktor Pendukung dan Penghambat Komunikasi Organisasi Muslimat dan 'Aisyiyah}

Faktor pendukung merupakan sesuatu hal yang dapat memperlancar segala usaha atau kegiatan yang dilakukan oleh organisasi. Untuk mencapai tujuan, organisasi melaksanakan suatu kegiatan yang membutuhkan kerjasama antar struktur yang ada dalam bentuk komunikasi partisipatif dari seluruh anggota (Nurdin, 2014 : 30). Sedangkan hambatan adalah faktor yang mempersulit tercapainya tujuan organisasi karena berbagai hal, yang salah satunya adalah kurangnya komunikasi antar pengurus dan anggota (Cangara, 2000 : 145). Adanya faktor-faktor pendukung dan penghambat dalam komunikasi organisasi adalah sesuatu yang wajar dalam setiap organisasi. Situasi dan kondisi ini membuat organisasi dapat belajar cara menyikapi dan mencari solusi.

Faktor pendukung komunikasi organisasi Muslimat diantaranya adalah berasal dari faktor internal anggota atau diri anggota yang aktif hadir dalam segala kegiatan yang diadakan organisasi. Pernyataan ini sesuai hasil wawancara dengan Ketua Muslimat NU Cabang Tandes sebagai berikut:

Faktor pendukung organisasi datang dari angggota sendiri, selama ini banyak yang hadir dalam setiap kegiatan baik silahturrahmi atau yang lainnya. Banyaknya anggota yang aktif sekarang hampir 100 lebih, padahal dulu hanya 75 orang saja (Wawancara dengan Nurul Jannah, 3 Mei 2019).

Faktor pendukung komunikasi lainnya adalah rasa nyaman dan leluasa dalam berkeluh kesah baik masalah organisasi maupun masalah pribadi (Wawancara dengan $\mathrm{Hj}$. Mining, 13 Mei 2019). Organisasi wanita ini masih tetap memerlukan bantuan dari kaum laki-laki. Ada beberapa fasilitas yang harus didukung dan dibantu oleh laki-laki. Misalnya, terkait dengan penyediaan tempat pengajian beserta peralatanya yang perlu dibantu persiapannya oleh kaum laki-laki (Wawancara dengan Hj. Yasifun, 8 Mei 2019).

Beberapa faktor penghambat komunikasi organisasi Muslimat berasal dari vakumnya kegiatan di tingkat Ranting karena anggota kurang aktif dalam mengikuti kegiatan yang diadakan oleh tingkat Cabang. Faktor kejenuhan anggota yang merasa bosan dan tidak tertarik dengan organisasi yang diikutinya. Ada juga karena faktor kehadiran anggota organisasi lain yang tidak diundang ketika kegiatan Muslimat berlangsung namun datang dalam kegiatan yang mempengaruhi dan mengganggu komunikasi. Akibatnya jumlah anggotanya semakin hari menurun (Wawancara dengan $\mathrm{Hj}$. Yasifun, 8 Mei 2019). 
Faktor pendukung komunikasi organisasi 'Aisyiyah adalah memiliki anggota yang berasal dari kalangan muda dan memiliki semangat yang tinggi dalam mengikuti segala kegiatan serta menjalankan tugas-tugasnya. Menurut informasi dari Ketua PCA Kecamatan Bulak, faktor pendukung dalam organisasi 'Aisyiyah adalah masyarakat sekitar memiliki antusias yang tinggi terhadap program-program yang dicanangkan, dengan begitu mereka senang hati untuk mengulurkan bantuan finansial pada kegiatan yang dilakukan (Wawancara dengan Mulyana, 1 Mei 2019). Pernyataan ini diperkuat dari hasil wawancara informan lain sebagai berikut :

Warga disini itu kalau diajak patungan langsung diberi. Dermawan orangnya. Karena mereka merasa bisa apalagi selain membantu secara finansial. Seperti kemarin kita mau membeli alat drumband, beli alatnya habis sekian juta hasil dari patungan orang-orang. Misalnya, mereka ke laut dapat lima jaring hasil tangkapan ikan, yang satu jaring dikasihkan ke 'Aisyiyah (Wawancara dengan Nur Hasanah, 7 Mei 2019).

Ketua Pimpinan Cabang 'Aisyiyah Kecamatan Tegalsari menyebutkan beberapa hambatan yang sering muncul dalam organisasi 'Aisyiyah yaitu adanya stigma-stigma negatif di lingkungan masyarakat mengenai Muhammadiyah terkait perbedaan pemahaman teks keagamaan yang dapat menghambat proses kaderisasi. Faktor lain yang merupakan hambatan pada organisasi 'Aisyiyah adalah berkembang isu pada generasi muda Muhammadiyah mengenai orientasi organisasi 'Aisyiyah. Mereka menganggap bahwa 'Aisyiyah merupakan organisasi yang hanya ditujukan bagi ibu-ibu atau orang tua saja serta hanya berisi kegiatan pengajian saja. Persepsi inilah yang membuat generasi muda enggan untuk bergabung dalam organisasi 'Aisyiyah (Wawancara dengan Nur Hasanah, 7 Mei 2019).

Faktor penghambat komunikasi organisasi 'Aisyiyah yang lain adalah kesibukan anggota yang sebenarnya mereka mampu dalam menjalankan organisasi namun terkendala oleh kesibukan mereka sebagai ibu rumah tangga, atau mereka yang memiliki kesibukan dalam bekerja atau sebagai wanita karier yang sulit membagi waktu untuk organisasi. Bagi sebagian organisasi organisasi 'Aisyiyah yang bertempat tinggal di pesisir pantai Kenjeran, faktor pendidikan menjadi penghambat dalam memberdayakan warga sekitar yaitu tingkat pendidikan yang masih rendah sehingga masih sedikit wanita yang berkeinginan untuk diajak berorganisasi (Wawancara dengan Mulyana, 1 Mei 2019).

Faktor pendukung komunikasi organisasi Muslimat dan 'Aisyiyah dapat dikaji dalam dimensi efektivitas kelompok (organisasi) yang menempatkan anggota untuk beraktivitas secara bersama dalam mencapai tujuan organisasi yaitu melaksanakan tugas organisasi, memelihara moral anggotanya, dan situasi organisasi yang menyenangkan (Rakhmat, 2012 : 157-158). Faktor penghambat dalam komunikasi organisasi Muslimat dan 'Aisyiyah dapat dikategorikan dalam hambatan psikologis yaitu hambatan yang terjadi karena permasalahan dalam diri individu, yaitu faktor kesibukan anggota dalam kegiatan yang menimbulkan kemacetan aktvitas dalam organisasi (Cangara, 2000 : 147). 


\section{PENUTUP}

Komunikasi organisasi wanita Muslimat dan 'Aisyiyah mengalami dinamika komunikasi yang selalu menyertai aktivitas organisasi tersebut. Dinamika yang terjadi memerlukan pengelolaan organisasi yang dibangun berdasarkan kompetensi komunikasi pengurus organisasi. Kompetensi komunikasi pengurus diperlukan dalam pembinaan dan kaderisasi anggota. Wanita memiliki karakter yang halus, lembut, dan sensitif dalam menjalankan roda kegiatan organisasi. Hal ini memerlukan model komunikasi kepemimpinan yang mampu menampung aspirasi seorang wanita.

Kompetensi komunikasi organisasi yang dimiliki oleh wanita Muslimat dan 'Aisyiyah terbukti mampu menggerakkan organisasi melalui pembinaan anggota, dan berhasil membentuk dan mengarahkan anggotanya untuk aktif dalam kegiatan dan dapat memberi dampak pada masyarakat sekitar. Melalui organisasi keagamaan wanita inilah, para wanita dapat aktif berkontribusi bagi masyarakat sekitar. Komunikasi pengakaderan anggota Muslimat dan 'Aisyiyah memiliki kecenderungan menggunakan pola komunikasi roda dan bintang, yaitu keseluruhan informasi berada pada level puncak organisasi (Ketua) dan mengacu pada keterbukaan komunikasi dan informasi yang dilakukan oleh seluruh elemen anggota organisasi tanpa melihat jabatan dalam organisasi. Model komunikasi kepemimpinan organisasi Muslimat dan 'Aisyiyah ditandai dengan adanya saling menghargai keputusan yang logis dan kreatif dari kesepakatan anggota organisasi dengan mendengarkan ide dan pendapat seluruh anggota untuk dijadikan sebagai keputusan organisasi. Faktor pendukung aktivitas organisasi adalah suasana kebersamaan dalam mencapai tujuan organisasi. Faktor penghambat kelancaran aktivitas organisai adalah suasana psikologis anggota dalam membagi waktu untuk kegiatan organisasi.

\section{REFERENSI}

Ahdiah, I. (2011). Organisasi Perempuan Sebagai Modal Sosial (Studi Kasus Organisasi Nasyiatul Aisyiyah Di Sulawesi Tengah). Academica, 3(1).

Aisyiyah. (2019). Identitas, Visi, dan Misi 'Aisyiyah | 'Aisyiyah. Http://Www.Aisyiyah.or.Id. Diperoleh dari (http://www.aisyiyah.or.id/id/page/identitas-visi-dan-misi.html)

Asmani, J. M. (2015). Kepemimpinan Perempuan: Pergulatan Wacana Di Nahdlatul Ulama (NU). Addin, 9(1).

Barrett, D. J. (2014). Leadership Communication, Fourth Edition. New York: McGraw-Hill Education.

Cangara, H. (2000). Pengantar Ilmu Komunikasi. Jakarta: Rajawali Press.

Diana, N. (2015). Kelahiran Muslimat NU. Skripsi (Yogyakarta: Universitas Islam Negeri Sunan Kalijaga Fakultas Adab Dan Ilmu Budaya, 2015).

Dzuhayatin, S. R. (2009). Menakar "Kadar Politis" Aisyiyah. Yinyang: Jurnal Studi Islam Gender Dan Anak, 4(2), 345-359.

Effendy, O. U. (2006). Ilmu Komunikasi Teori dan Praktek. Bandung: PT Remaja Rosdakarya.

Fatikh, M. A., \& Panuju, R. (2018). Komunikasi Organisasi Kehumasan Polres Pasuruan. Jurnal Riset Komunikasi, 1(1), 22-34.

Harianto, E. (2018). Empat Pilar Pendidikan Muhammadiyah. Prosiding Konferensi Nasional Ke- 7 Asosiasi Program Pascasarjana Perguruan Tinggi Muhammadiyah Aisyiyah (APPPTMA). 
Imamah, F. M., \& Firlana, A. R. (2019). Kepemimpinan Perempuan Dalam Organisasi Muslimat dan "Aisyiyah di Kabupaten Tulungagung Perspektif Living Quran. Jurnal SMART (Studi Masyarakat, Religi, Dan Tradisi), 5(2), 229-242. https://doi.org/10.18784/smart.v5i2.877

Indriastuti, Y. (2018). Kompetensi Komunikasi Politik Politisi Perempuan Jawa Timur. Jurnal Kajian Media, 2(1).

Jubaedah, E. (2009). Analisis hubungan gaya kepemimpinan dan kompetensi komunikasi dalam organisasi. Jurnal Ilmu Administrasi: Media Pengembangan Ilmu Dan Praktek Administrasi, 6(4), 04. https://doi.org/10.31113/jia.v6i4.360

Korhonen, K. E. (2002). Intercultural Competence as Part of Professional Qualifications. A Training Experiment with Bachelor of Engineering Students. Jyväskylä : University of Jyväskylä.

Kuswarno, E. (2009). Fenomenologi: Konsepsi, Pedoman, dan Contoh Penelitiannya. Bandung: Widya Padjadjaran.

Makruf, S. (2019). Pengkaderan Da'iah Melalui Pelatihan Retorika Dakwah (Kelompok Kajian Ibu-Ibu 'Cengkir Gati'di Dusun Sawahan Nogotirto Gamping Sleman). Jurnal Abdimas Madani Dan Lestari (JAMALI), 1(01), 47-52.

Meizara, E., Dewi, P., \& Basti, B. (2016). Analisis Kompetensi Kepemimpinan Wanita. Jurnal Ilmiah Psikologi Terapan, 4(2), 175-181.

Miles, M. B., \& Huberman, A. M. (1992). Analisis data kualitatif. Jakarta: UI press.

Moeleong, L. J. (2008). Metodologi Penelitian Kualitatif. Bandung: PT. Remaja Rosdakarya.

Muslimat NU. (2015, March 30). Sekelumit Profil, Sejarah dan Prestasi Muslimat NU. Diperoleh dari (https://www.nu.or.id/post/read/58517/sekelumit-profil-sejarah-danprestasi-muslimat-nu)

Nidyansari, D. A. (2018). Ketidakharmonisan Komunikasi Dalam Keluarga Pada Pembentukan Pribadi Anak (Pendekatan Humanistik). Jurnal Riset Komunikasi, 1(2), 74-85.

Nurasmah. (2018). Kepemimpinan Perempuan Pada Organisasi Sosial Keagamaan [Skripsi]. Program Studi Psikologi fakultas Ilmu Sosial dan Humaniora UIN Sunan Kalijaga.

Nurdin, A. (2014). Komunikasi Kelompok dan Organisasi. Surabaya: UIN Sunan Ampel Press.

Nurdin, A. (2015). Komunikasi Magis; Fenomena Dukun di Pedesaan. LKiS Pelangi Aksara.

Nurhidayah, Y. (2017). Pola Komunikasi Perempuan Pesisir: Studi Etnografi Komunikasi. Communicatus: Jurnal Ilmu Komunikasi, 1(2), 209-231. https://doi.org/10.15575/cjik.v1i2.5060

Pimpinan Pusat Aisyiyah. (2007). Sejarah Pertumbuhan dan Perkembangan Aisyiyah. Yogyakarta: PP. Aisyiyah.

Pramitha, D. (2018). Kepemimpinan Kolektif di Pondok Pesantren (Studi Multisitus di PP. Tebuireng Jombang, PP. Bahrul Ulum Tambakberas Jombang, dan PP. Mambaul Ma'arif Denanyar Jombang). J-PAI: Jurnal Pendidikan Agama Islam, 4(2). http://dx.doi.org/10.18860/jpai.v4i2.6257

Rahim, A. (2016). Peran Kepemimpinan Perempuan Dalam Perspektif Gender. $A L$ MAIYYAH: Media Transformasi Gender Dalam Paradigma Sosial Keagamaan, 9(2), 268-295.

Rahminawati, N., AR, N. H., \& Umar, T. M. (2006). Kemampuan Manajerial Pengurus Organisasi dalam Upaya Meningkatkan Kinerja Organisasi Islam Perempuan Di 
Jawa Barat. MIMBAR: Jurnal Sosial Dan Pembangunan, 22(2), 143-164. https://doi.org/10.29313/mimbar.v22i2.206

Rakhmat, J. (2012). Psikologi Komunikasi. Bandung: PT. Remaja Rosdakarya.

Rival, V., \& Mulyadi, D. (2010). Kepemimpinan dan Perilaku Organisasi. PT Rajagrafindo Persada.

Sari, H. (2018). Pola Komunikasi Da'iyah dalam Pembinaan Keagamaan di Muslimah Wahdah Islamiyah Daerah Makassar. NUKHBATUL'ULUM: Jurnal Bidang Kajian Islam, 4(1), 51-60. https://doi.org/10.36701/nukhbah.v4i1.33

Situmorang, N. Z. (2011). Gaya kepemimpinan perempuan. Proceeding PESAT, 4.

Wati, I. S., \& Agustono, R. (2017). Peran Siti Walidah Di Bidang Pendidikan dan Sosial Dalam Perkembangan Aisyiyah Tahun 1917-1946. SWARNADWIPA, 1(2).

Zamroni, M. (2013). Perempuan dalam kajian komunikasi politik dan gender. Jurnal Dakwah, 14(1), 103-132. https://doi.org/10.14421/jd.2013.14105 